\title{
粒子法ポストプロセッシングによる落水表情の表現 \\ POSTPROCESSOR OF PARTICLE METHOD FOR VISUAL EXPRESSION OF FALLING WATER
}

\author{
後藤仁志 ${ }^{1} \cdot$ 橋本麻未 $^{2} \cdot$ 五十里洋行 ${ }^{2} \cdot$ 酒井哲郎 $^{3}$ \\ Hitoshi GOTOH, Mami HASHIMOTO, Hiroyuki IKARI and Tetsuo SAKAI \\ ${ }^{1}$ 正会員 工博 京都大学助教授 工学研究科都市環境工学専攻（广 $606-8501$ 京都市左京区吉田本町） \\ 2学生会員 京都大学大学院 工学研究科都市環境工学専攻（同上） \\ 3フェロー 工博 京都大学教授 工学研究科都市環境工学専攻（同上）
}

\begin{abstract}
In late years, the techniques of the CFD for the free-surface flow are developing rapidly. On the other hand, study of the computer graphics (CG) to express a complicated natural phenomenon is conducted actively, and the methods to get realistic CG of natural phenomena with fluid motion, such as a cloud, a flame and a current, have been proposed. The representative of these methods in CG is the particle system. In this study, the simple motion rule of particle in the particle system is improved by introducing the MPS(Moving Particle Semi-implicit) method, which is a solver of the Navier-Stokes equation, to combine the Lagrangian physical model of fluid with the Lagrangian tool of CG. Furthermore, the sub-particle scale expression of mists is described by the Monte Carlo simulation of the mist particles, based on the concept of the DDM (discrete droplet model). Finally the physical CG of a falling water is shown.
\end{abstract}

Key Words: $\quad$ MPS method, postprocessing, particle system, mist, discrete droplet model

\section{1. 緒 言}

近年のハードウェアの著しい進歩は, 高負荷の計算 コードを実行可能にしてCFDを発展させ,これまでな ら平均化せざるを得なかったような場の詳細な構造の 時空間特性を数值的に捕らえることが可能となってき た.このことは同時に, 後処理の高負荷化を意味し, シミュレーション結果の可視化がCFDにとっての重要 な研究課題として浮上した。いわゆる, Scientific Visualizationである。CFDにおけるScientific Visualizationは専門知識を有する研究者・技術者のた めのものであるから, 現象のメカニズムを把握するた めに必要な情報（物理量分布）が視覚化され, 直感的 把握の助けとなれば充分である. したがって，グラ フィックスとしての『質』（写実性，芸術性等）の問 題は重要ではなく，木来なら目に見えない物理量（例 えば流速べクトル等）を如何に直感的に把握し易い形 式で表示するかに注意が向けられてきたと言えるだろ う。一方, CG制作の実務では写実性こそが最重要な 要素であり, 物理法則に基づく結果よりも映像製作者 のセンスが優先され，たとえ物理ベースのCGを導入
した場合でも加筆修正に多大の時間が費やされること が多い。このように一口にCGと言っても, 科学のツー ルから芸術的職人技まで広いスペクトルを有している.

工学的な見地からすると, 染意的な判断を排除する 合理性の追及が必要だろうから, オーディエンスが実 物と見紛うような映像を制作するための方法論の確立 が，工学におけるCG研究の本質と言うことができる だろう.つまり，一定の手続きに沿つて映像を制作す れば, 製作者が誰であっても同じ出来栄えのCGが得 られる手法を開発することである. 例えば映画制作で のCGの対象となるのは実写では実現が困難であった り極端な高コストを必要とするような衝突・破壊といつ た現象であり, 破片の飛散現象の再現が写実性の鍵と なる.このような需要に応えるために開発されたのが,

『パーティクルシステム』である. この方法では, 大 量の粒子を一定の運動規則（いわゆる粒子の運動方程 式とは異なる簡便な規則）にしたがって移動させて得 られる粒子群をレンダリングして, 対象物体のボリュー ムを表現する. 例えば，写実的CGの制作が最も難し いと言われる雲・炎・水流等の流体運動を伴う自然 現象のCG制作にも，『パーティクルシステム』が適 
用され，成果を挙げている（例えば, Chibaら $\left.{ }^{1)}\right)$.

このような研究の現状を見ると，CDFとCGの融合 に新しい可能性が浮かび上がってくる.すなわち, 現 状のパーティクルシステム型CGで過度に単純化され ている粒子運動規則を，本来の物質小片（流体塊や固 体破片など）の物理的な特性を反映した運動方程式へ と深化させるシナリオである. パーティクルシステム はその名の示す通り, 粒子分散系の運動をCG化する 手法であり, Lagrange型の力学モデルとの馴染みがよ いのは言うまでもない.

近年, 急変流解析への取り組み (VOF法, C-CUP 法, 粒子法など）が活発化しつつあるが, 粒子法は, 水塊分裂に単純なアルゴリズムで柔軟に対応できる特 徵を有しているので, 砕波・越波時の飛沫の発生など の複雑な水塊分裂に対して, 連続体近似に基づく諸手 法と比較すると, 特段の後処理なしにでも写実性の面 で優位にある（単に比較優位であって，本格的CGと は歴然とした相違があるのは言うまでもないが）。こ のような認識から著者ら ${ }^{2)}$ は, MPS法のポストプロ セッシングとしてのパーティクルシステム型CGの作 成方法を検討し, 飛沫を伴う砕波過程・越波過程に適 用したが, 飛沫のイメージ作成は単純モンテカルロ法 による簡便なもので，飛沫の空間スケールなどの物理 情報に関しても経験的な処理に留まっていた。

本稿では, SPS(Sub-Particle-Scale)表情モデルとして のmist拡散過程の取り扱いに大幅な改善を行い, jet breakup を伴う落水の多彩な表情表現に適用する. 一 連の結果を通じて, Navier-Stokes式を物理システムと して有するパーティクルシステムにおけるSPS表情モ デルの役割を明確化する.

\section{2. 物理過程のシミュレーション}

\section{(1) PSモデル}

本研究では, CGの骨格, すなわち particle scale (PS) の構造をMPS法 (Koshizuka・ $\mathrm{Oka}^{3)}$ ) によって 計算する. MPS法では, 計算領域に配置された多数 の粒子（計算点）間の相互作用として基礎式の各項 が離散化されるため，計算格子が不要である．ま ず，均一で質量が変化しない粒子を用い，粒子数密 度（単位体積あたりの粒子数）を一定値 $n_{0}$ に保つこ とにより, 非圧縮条件が満足される.

一方, 運動方程式（Navier-Stokes 式）

$$
\frac{\partial \mathbf{u}}{\partial t}+(\mathbf{u} \cdot \nabla) \mathbf{u}=-\frac{1}{\rho} \nabla p+v \nabla^{2} \mathbf{u}+\mathbf{g}+\frac{\sigma \kappa \delta}{\rho} \mathbf{n}
$$

(u : 流速ベクトル, $p$ : 圧力, $\rho:$ 流体（水）の密度, $\mathbf{g}$ : 重力加速度べクトル, $v$ : 渦動粘性係数, $\sigma$ : 表面 張力倸数, $\kappa$ : 表面曲率, $\delta$ : デル夕関数, $\mathrm{n}$ : 法線方 向の単位ベクトル）については, 粒子周囲の影響円内
の他の粒子との相互作用を通じて離散化される (越塚 ${ }^{4)}$ ) 。移流項は粒子移動の追跡を通じて計算さ れるため, 移流項の差分化に起因する数值拡散が生じ ない.

粒子 $i$ の圧力項(gradient)および粘性項(Laplacian)は,

$$
\begin{gathered}
-\frac{1}{\rho}\langle\nabla p\rangle_{i}=-\frac{1}{\rho} \frac{D_{0}}{n_{0}} \sum_{j \neq i}\left\{\frac{p_{j}-p_{i}}{\left|\mathbf{r}_{i j}\right|^{2}} \mathbf{r}_{i j} \cdot w\left(\left|\mathbf{r}_{i j}\right|\right)\right\} \\
v\left\langle\nabla^{2} \mathbf{u}\right\rangle_{i}=\frac{2 v D_{0}}{n_{0} \lambda} \sum_{j \neq i}\left(\mathbf{u}_{j}-\mathbf{u}_{i}\right) w\left(\left|\mathbf{r}_{i j}\right|\right) \\
\mathbf{r}_{i j}=\mathbf{r}_{j}-\mathbf{r}_{i}
\end{gathered}
$$

のように，粒子周囲の影響円内の他の粒子との相互作 用としてモデル化される $\left(D_{0}\right.$ : 次元数, $\lambda$ : モデル定 数）。粒子間相互作用が生じる範囲（影響円）は, 重 夕関数

$$
w(r)= \begin{cases}\frac{r_{e}}{r}-1 & \text { for } r \leq r_{e} \\ 0 & \text { for } r>r_{e}\end{cases}
$$

により規定される（Koshizuka・Oka $\left.{ }^{3)}\right)$ ．また，粒子 数密度は重み関数を用いて

$$
\langle n\rangle_{i}=\sum_{j \neq i} w\left(\left|\mathbf{r}_{j}-\mathbf{r}_{i}\right|\right)
$$

と定義される。なお, MPS法の詳細に関して は，越塚 ${ }^{4)}$ による解説が有用である.

表面張力の評価に関しては, 粒子数密度から表面 曲率を推定し, 表面張力を体積力に換算して, 水面 粒子に与えるNomuraら5) のモデルを用いた。なお, 粒子数密度に基づいて判別される標準型のMPS法の 水表面は, 粒子径の数倍の厚みがあるので, 表面張 力の作用域を粒子径程度の厚さ（体積力換算するの でこれ以下には設定できない）に制限するため，粒 子数密度のレベルだけでなく, 粒子数密度の空間的 偏在性を指標とする後藤ら ${ }^{6)}$ の水面粒子の判定基準 を導入した.

\section{(2) SPS表情モデル}

落下水脈は気相中に噴出されたジェットに相当す るから，ある距離以上はその形状を維持できずに液 滴に分裂する（いわゆる jet breakup）。液滴は気相 中でせん断変形や回転による遠心力の影響を受けて 液膜状に変形し, さらなる微細液滴群 (mist, 霧) へと分裂する．原則論としては，液滴の分裂過程自 体についても流体力学的なアプローチを採るべきで はあるが，単相流の粒子法をべースとした展開を考 えている本稿では, 分裂過程の詳細まで力学的に記 述することは難しい，そこで，孤立粒子の中心に重 心を有する mist粒子の拡散過程をLagrange的な粒子 


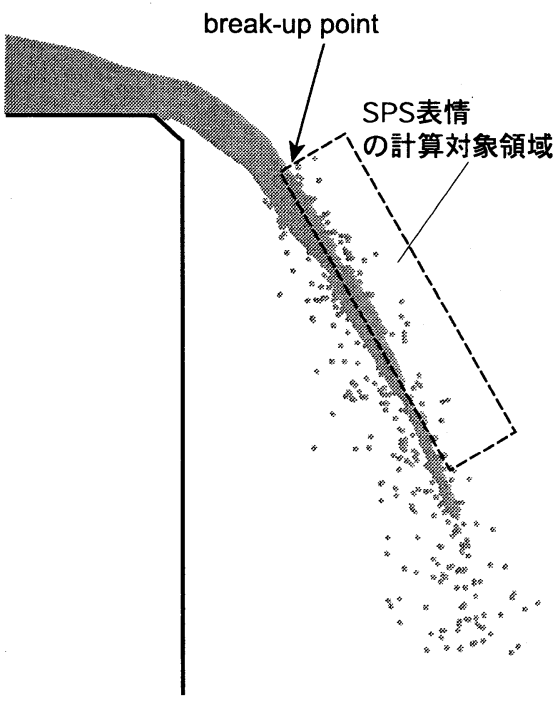

(a) 計算領域のイメージ

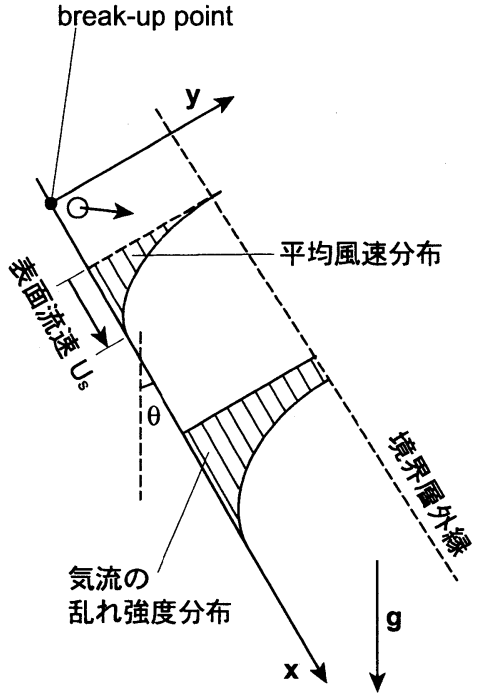

(b) 座標系（風速場）

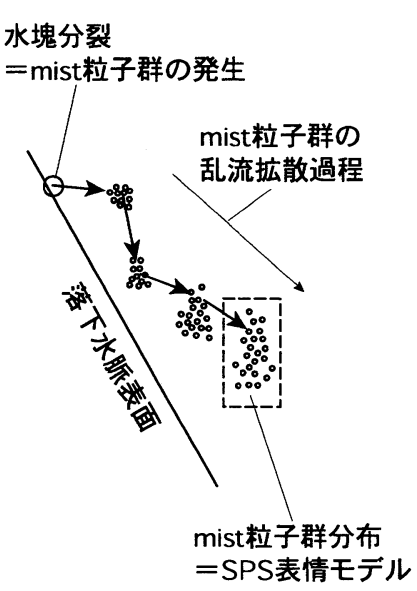

(c) mist拡散過程のイメージ

図-1＼cjkstart計算領域・座標系

追跡によって記述することで, MPS法の粒子スケー ル以下のmistの挙動を記述する方法を選択した。 mist粒子群の姿は, MPS法の粒子スケール以下の物 理現象の結果であるから,これをSPS表情モデルと 呼ぶことにする.

計算領域のイメージと座標系およびmist拡散過程 の概念を図-1に示す. mist粒子の拡散過程の追跡は breakup pointより上流側では不要であるので, 追跡 の座標原点をbreakup pointに設定する。なお, breakup pointの位置は，近接して複数（近傍粒子検 索円（ $r=2.1 d ）$ 内に2個以上）の孤立粒子が発生する 座標を時間平均して定めることとした. 気相は静止 状態にある（落水周辺の気流の大規模な循環は考慮 の外）と仮定すると, 落下流速に相当する大きさの 相対速度が落水と周辺気相の間に存在するので, 落 水表面付近の気相にはこれを緩和するための風速分 布が生じることとなる．このことを落水表層に固定 された座標系から見て, 落水表面を固定滑面と見立 てると, 大略的には壁面乱流と相似と見なせるだろ う. 風速勾配のある層内での対数則の成立を想定 し，（本来は，落下流自体が加速流であるが）準定 常的な取り扱いを行うと, 落下流に沿う空気層の風 速分布は,

$$
\frac{U-U_{s}}{u_{*}}=-\frac{1}{\kappa} \ln \frac{u_{*} y}{v}+C_{s}
$$

となる．ここに， $U_{\mathrm{s}}$ : 落下流の表面流速， $u_{*}$ : 摩擦 速度, $\kappa$ : カルマン定数, $C_{\mathrm{s}}$ : 滑面対数則の定数 (=5.5)である.

落下流に沿う空気層の厚さ（落下流の影響域のス ケール）については, 平板上の乱流境界層厚さ

$$
\delta_{b l t}=0.38\left(\frac{U_{s} x_{f w s}}{v}\right)^{-1 / 5} x_{f w s}
$$

で与えた.ここに, $x_{\mathrm{fws}}$ : 平板端部からの距離である が，ここでは，落下水脈に沿う越流頂からの距離で 代用した。 なお，このような扱いでは水面曲率の影 響による境界層厚さの変化を考慮できないが，SPS 表情が主たるターゲットであるので, 物理情報とし ては粗い近似を敢て選択して取り扱いを簡便なもの とするよう配慮している. なお, 式(7)中の摩擦速度 に関しては, 境界層外縁で水脈の主流方向の平均風 速がゼロであることから得られる条件式

$$
\frac{U_{s}}{u_{*}}=\frac{1}{\kappa} \ln \frac{u_{*} \delta_{b l t}}{v}+C_{s}
$$

を解いて求めることができる. 落下流に沿う空気層 における乱れ強度の $x, y, z$ 成分は,

$$
\begin{aligned}
& \frac{\sqrt{\overline{u^{\prime 2}}}}{u_{*}}=2.3 \exp \left(-\frac{y}{\delta_{b l t}}\right) \\
& \frac{\sqrt{\overline{v^{\prime 2}}}}{u_{*}}=1.27 \exp \left(-\frac{y}{\delta_{b l t}}\right) \\
& \frac{\sqrt{\overline{w^{\prime 2}}}}{u_{*}}=1.63 \exp \left(-\frac{y}{\delta_{b l t}}\right)
\end{aligned}
$$

で与えることとする.これらの式は, 開水路におけ る禰津 ${ }^{7)}$ の乱扎強度分布の普遍関数表示の水深を境 界層厚さに読み替えた表示であるが，本表示の妥当 


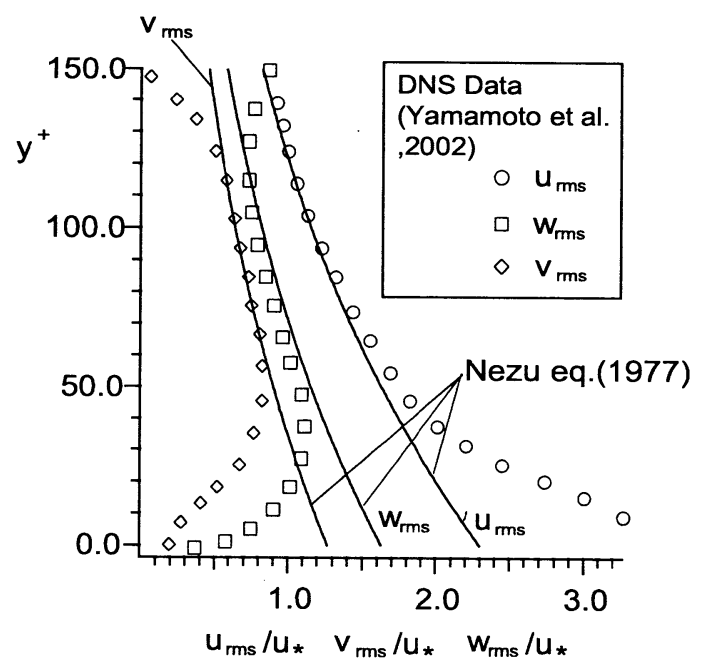

図-2 気相の乱れ強度分布

性を確認するため, 山本ら ${ }^{8)}$ による水面近傍気相の DNSデータと比較したのが図-2である．この場合 も，開水路滑面と同様に壁（この場合には水面）の 極近傍を除けば，襧津の普遍関数表示の配分率が概 ね妥当なことが分かる.

個々のmist粒子の周囲流体の風速の変動成分は, 単純モンテカルロ法に基づき,

$$
\left.\begin{array}{rl}
u(t) & =r_{\mathrm{u}} \cdot \sqrt{\overline{{u^{\prime 2}}^{2}}} \\
v(t) & =r_{\mathrm{v}} \cdot \sqrt{\overline{{v^{\prime 2}}^{2}}} \\
w(t) & =r_{\mathrm{w}} \cdot \sqrt{\overline{{w^{\prime 2}}^{2}}}
\end{array}\right\}
$$

で与える.ここに，( $\left.r_{\mathrm{u}}, r_{\mathrm{v}}, r_{\mathrm{w}}\right)$ : 標準正規乱数であ る.

mist粒子の運動は, 乱流中の球の運動方程式

$$
\begin{gathered}
\rho_{a}\left(\frac{\rho}{\rho_{a}}+C_{M}\right) A_{3} d_{m}^{3} \frac{\mathrm{d} \mathbf{u}_{m p}}{\mathrm{~d} t}= \\
\quad \frac{1}{2} \rho_{a} A_{2} d_{m}^{2} C_{D}\left|\mathbf{u}-\mathbf{u}_{m p}\right|\left(\mathbf{u}-\mathbf{u}_{m p}\right) \\
+\rho_{a}\left(1+C_{M}\right) A_{3} d_{m}^{3} \frac{\mathrm{d} \mathbf{u}}{\mathrm{d} t} \\
+\rho_{a}\left(\frac{\rho}{\rho_{a}}-1\right) A_{3} d_{m}^{3} \mathbf{g} \\
C_{D}=\frac{24}{R_{e}}\left(1+0.15 R_{e}^{0.687}\right) ; R_{e}=\frac{\left|\mathbf{u}-\mathbf{u}_{m p}\right| d_{m}}{v}
\end{gathered}
$$

にしたがって計算する，ここに， $\rho_{\mathrm{a}}$ : 空気の密度, $C_{\mathrm{M}}$ : 付加質量係数 $(=0.5), A_{2}, A_{3}:$ mist粒子の 2 次元 および 3 次元形状係数（球を仮定して, $A_{2}=\pi / 4$, $A_{3}=\pi / 6 ）, \mathbf{u}:$ mist粒子近傍風速, $\mathbf{u}_{\mathrm{mp}}$ : mist粒子速 度, $d_{\mathrm{m}}$ : mist粒子径, $C_{\mathrm{D}}$ : 抗力倸数, $\mathbf{g}$ : 重力加速度
ベクトルである.

mist粒子の追跡は, breakup pointにおける水脈の表 層直上から開始した。ところで，水脈の表面と裏面 ではMPS法の孤立粒子の平均的運動性状が異なる. 水脈の表面側に放出された孤立粒子は重力の影響で 水脈に引き戻される向きに運動するが, 水脈の裏面 側では重力は孤立粒子を水脈から遠ざける方向に作 用する. mist粒子もこれと同様の境界条件で運動す るから，水脈の表裏両面について，mist粒子の空間 分布の時間発展を計算した。

水脈と接触したmistについては, 水脈表面に吸収 される場合もあれば，反発して水脈から遠ざかる場 合もある. 液滴の固体壁との衝突に関しては, 衝突 Weber数による液滴挙動の相違がWakisakaら ${ }^{9)} に よ$ り示されているが, 液膜との衝突に関しては明確な 判定基準が提案されていない，そこで，mist粒子は 水脈表面で鏡像反射するものとして，水膜による mistの吸収を無視して取り扱った.

図-3は，breakup pointの水脈表面および裏面から放 出されたmist粒子群の挙動の追跡結果を示してい る. なお, 図中のsourceは各時間のmist分布の初期の 座標を意味している. 表側のmist粒子は水脈表面付 近に薄く引き伸ばされながら膜状に分布しつつ落下 する様子が分かる. これに対して, 水脈裏側に放出

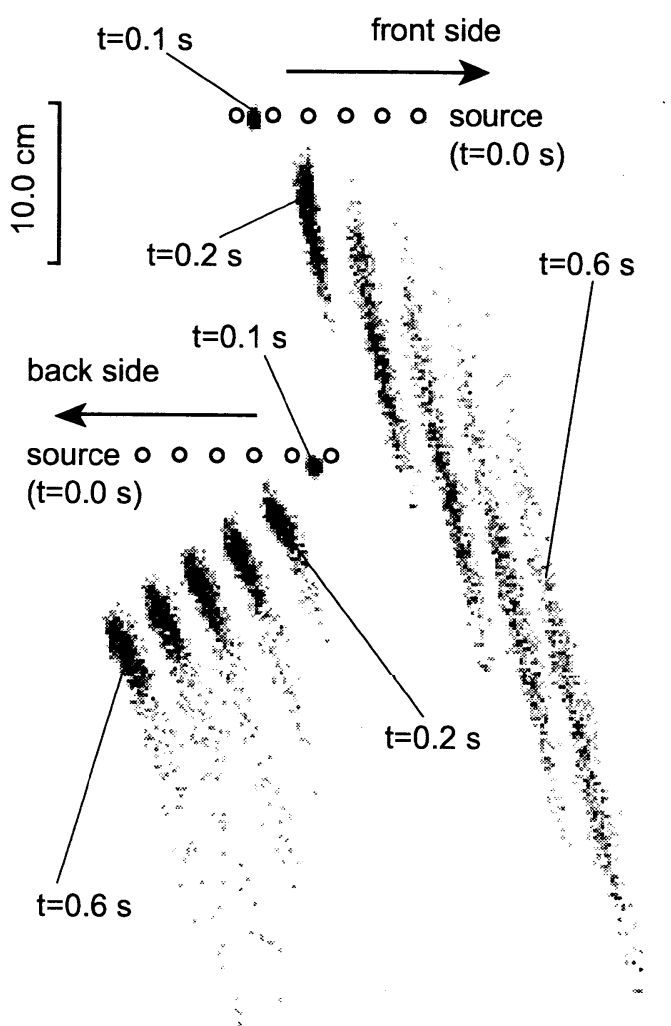

図-3 mist粒子群の挙動 
されるmist粒子群は，速度せん断層を通過する際に 一部が薄く引き伸ばされるが，大部分は重心付近に 留まり，表側のmistとは分布に大きな相違が生じて いる.

\section{(3) パーティクルシステムの構成}

CGの制作過程は，モデリングとレンダリングに分 けられる.いわゆる座標データの生成（より正確に は，グラフィックス対象物体の形状や物性等の数值 情報の設定）がモデリングであり，本稿ではMPS法 の本計算がモデリングと言うことになる．これに引 き続く描画のプロセスであるレンダリングは, MPS 法側から見るとポストプロセッシングと呼べる.

レンダリングには, レイトレーシングを用いた.

レイトレーシングは, 視点に届く光線を逆にたどる ことによって物体の表面の反射率や透明度・屈折率 などを細かく反映させることができる特徵を有して おり，高画質CG作成に標準的に用いられる手法であ る.レイトレーシングには, POV-Ray(Persistence of Vision Ray Tracer; http;//www.povray.org/)を用いた. POV-Ray（解説書としては，小室 ${ }^{10}$ )）は，高性能 フリーウェアとして広く知られており, web上に多く 関連プログラム群を有し，パーティクルシステム型 のinclude file（拡張プログラム）もフリーウェアとし て提供されている.

しかし, 既存のパーティクルシステムは, レンダ リングと同時並行での処理，言い換えるとレンダリ ングに付随する粒子追跡，を目的としており，先に も述べたように，計算負荷を押さえつつ，極端に単 純化した粒子の運動規則に基づいて流体の举動を描 こうとするものである.このようなパーティクルシ ステムの設計は，予め詳細に描かれたマット（背景 画）上に，局所的な流体運動を伴うイメージ（例え ば，噴水や火炎など）を描き重ねるといったCG制作 の常識に照らして開発されているので, 物理過程の 計算負荷を厭わないphysical CGの作成を考えると使 いやすい形式とはなっていない。そこで, 物理計算 の後処理（ポストプロセッシング）としてのパー ティクルシステムの構成が必要となる.

著者らは, 砕波・越波過程のポストプロセッシン グ2)において飛沫粒子の拡散過程をサブモデルで記 述し，MPS法の孤立粒子上に貼り重ねる方法を提案 して, 流体・水表面・飛沫（孤立）の3つのカテゴ リーに粒子を分類し，それぞれのカテゴリーに個別 の特有の画像イメージをレンダリングしてCGを作成 した．通常のMPS法では，粒子は 2 つのカテゴリー

（流体粒子，水表面粒子）に分類される。これは, 水表面での圧力の境界条件を指定する都合上必要な 分類であるが，水塊の表情に着目すると，流体粒 子・水表面粒子に加えて第 3 のカテゴリーとして飛
沫粒子（孤立粒子）が必要となる。これには，粒子 数密度レベルと粒子数密度の空間的偏在性を指標と する水面粒子の判定基準（後藤ら ${ }^{6)}$ ）を用いた。 流 体粒子に関しては外周を構成する粒子を連結して一 体化することによりポリゴンを形成し，屈折率を 1.33 に設定して水の質感を表現した。水表面粒子に 関しては，球体（いわゆる水玉，屈折率1.33）とし て扱った. 孤立粒子については, SPS表情モデルで得 られるmist群の画像を個々のMPS法の粒子の孤立持 続時間に応じて個別にレンダリングして，個々の孤 立粒子の発生時間と発生場所に依存するイメージが CGに反映されるようにしている.

本稿の方法は, 粒子法ポストプロセッシングとし ての著者らのフレームワーク ${ }^{2)}$ に基づくものではあ るが，以下の点について新たに改良を加えた。 (1)こ れまでは，等方的な拡散過程に限定されていたサブ モデルを改良し，非等方化した。(2)水面近傍の風速 場の乱れに駆動される mistの拡散の物理的側面を考 慮した. (3) mistの挙動の異方性を表現可能にした. (4)個々の孤立粒子の発生時間と発生場所に依存する イメージの相違を反映してCGのディテールを構成し た. (5)さらに，このモデルにSPS表情モデルとして の明確な位置付を与えた。

\section{3. 落水表情のポストプロセッシング}

\section{（1）計算領域・計算条件}

MPS法の計算では, 越流部の上流側に設けたタン クの底面を一定速度で上昇させる方法で一定流量を 供給し, 定常状態を実現している。単位幅流量 $q=0.05 \mathrm{~m}^{2} / \mathrm{s}$, 越流水深を距離スケールとするReynolds

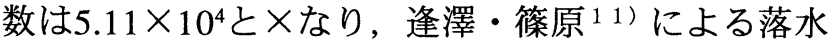
表情の領域区分では「2次元乱れ」と表現されてい る領域に相当する．このモードでは越流直後にjet breakupが発生し, 膜状の領域は越流頂直下の範囲に 限定される。なお, 越流頂の形状は, 標準型越 流頂 ${ }^{12)}$ の曲線形を直線壁のセグメントを連絡して 近似している。

MPS法の計算時間間隔は, $\Delta t_{\mathrm{MPS}}=0.5 \times 10^{-4} \mathrm{~s}$, 粒子 径は均一で, 粒子径 $d=0.5 \mathrm{~cm}$, 粒子総数 26958 個（そ の内，固定壁粒子11775個）である．mist粒子は粒径 $d_{\mathrm{m}}=0.2 \mathrm{~mm}$ （霧雨の雨滴相当）として, 単一のMPS 法の粒子に対して, 500個のmist粒子を発生させた. 体積比から計算すると, MPS法の1粒子に対してmist 粒子15625個が発生する必要があるので, 現実のmist 粒子約30個を1個のmist粒子で代表させるDSMC (direct simulation Monte Carlo)的な扱いとなっている

(mist粒子間の衝突は考慮していないので, 最も簡 略な様式のDSMCであはるが）。 


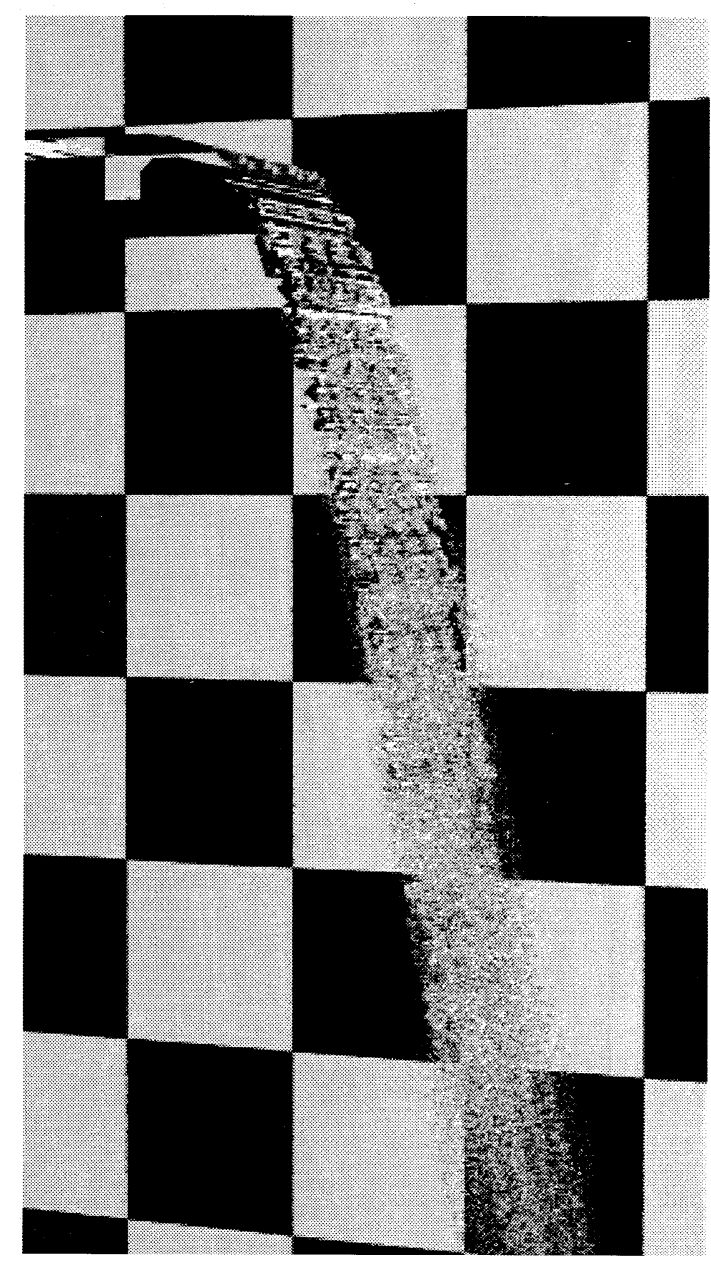

図-4 落水表情のCG

\section{(2)落水表情のCG}

図-4に，本稿の方法で得られたCGの一例を示す。 落水を特徽付けるjet breakupの存在が明確に現れてい る. breakup point より上流側の水面は僅かな水面波 を伴う程度で滑らかであるが, breakupが発生すると 大量のmistが水膜表面を覆う様子が再現されてい る. 水膜から分離生成される mistの表情は, 流下方 向に著しく異なり，水脈が落下するに従って白濁し た雲状の塊が成長する様子が再現されている.な お,レイトレーシングは 3 次元に対応しているの で，粒径の40倍の奥行きを有するシリンダー群（鉛 直断面がMPS法の粒子配置に一致）を対象としてポ リゴン生成し, mist粒子は3Dテクスチャーとして, 奥行き方向に4列放出して処理した. MPS法のシミュ レーションが鉛直2次元場を対象としたものであるの で, 現段階ではCGも疑似3Dとなっている.

\section{4. 結 語}

以上のように，落水を特徵付けるjet breakupの存在 が粒子法という物理モデルによって明確に記述され
た.さらに, jet breakupによって生成されたmistの拡 散過程にランダムウォーク型の粒子追跡モデル適用 して，サブ粒子スケールの表情を描くことにより， 落水の多彩な表情を表現することが可能となった.

逢澤・篠原 1 1) も指摘しているように, 流水・落水 表情は日本人の美意識の代表的な要素であり, 都市 の水辺空間の設計において中心的要素の一つであ る. 逢澤・篠原がその設計に経験水理学とCGを用い たのに対して, 本稿では, 経験水理学をブレイクス ルーして, CFDとCGの融合を軸としたフレームワー クを示した。

粒子法は並列化・3次元化の段階に入りつつあり, 3D物理モデルとの融合も近い将来に実現されるだろ う. 自由表面流れの解析手法は急速に発展しつつあ り, 景観水理学に対するHydrodynamicsの貢献には, 今後の期待が大きい.

\section{参考文献}

1) Chiba, N., Sanakanishi, S., Yokoyama, K., Ootawara, I., Muraoka, K. and Saito N.: Visual Simulation of Water Currents using a Particle-based Behavioural Model, Jour. Visualization and Computer Animation, Vol. 6, pp. 155$171,1995$.

2) 後藤仁志・橋本麻未-五十里洋行 - 酒井哲郎 : 砕波表 情表現のための粒子法ポストプロセッシングの提案, 海岸工学論文集, 第50巻, 2003 (印刷中).

3) Koshizuka, S. and Oka, Y.: Moving-particle semi-implicil method for fragmentation of incompressible fluid, Nuclear Science and Engineering, Vol. 123, pp.421-434, 1996.

4) 越塚誠一：数值流体力学, インテリジェントエンジニ アリングシリーズ, 培風館, p223, 1997.

5) Nomura, K., Koshizuka, S., Oka, Y. and Obata, H.: Numerical Analysis of Droplet Breakup Behavior using Particle Method, Jour. Nucl. Sci.and Tech., Vol. 38, No. 12, pp.1057-1064, 2001.

6) 後藤仁志・五十里洋行・八木哲生・酒井哲郎 : MPS法 よる砕波解析のための自由水面境界条件の改良, 海岸 工学論文集，第50巻, 2003 (印刷中).

7) 螎津家久:開水路乱流の乱れ強度に関する研究, 土木 学会論文報告集，第261号, pp.67-76, 1977.

8）山本義暢・功刀資彰・佐竹信一：気液せん断乱流場に おける界面近傍の乱流特性の直接数值計算, 第16回数 值流体力学シンポジウム論文集, E13-3, 2002.

9) Wakisaka, T., Shimamoto, Y., Isshiki, Y., Noda, T, Matsui, A. and Akamatsu, S.: Numerical Analysisi of Spray Phenomena in Fuel Injection Engines, Int'l. Symp. COMODIA 94, pp403-409, 1994.

10) 小室日出樹 : POV-Ray ではじめるレイトレーシング, ASCII 出版, p382, 1999.

11) 逢澤正行・篠原 修: 自由落下型と越流型の落水表情 についての実験的研究, 土木学会論文集, No. 593/II43, pp.105-115, 1998.

12) 水理委員会編：水理公式集（平成11年版）, p713, 土 木学会, 1999.

(2003.9.30受付) 